\title{
Towards a Sustainable Happiness Model for UAE: Lessons from Latin America
}

\author{
Dr Vidya Nandagopala* \\ aUniversity of Dubai, UAE. \\ *Corresponding author. \\ Received: 30 October 2018, accepted: 30 October 2018, published: 3 March 2019
}

\begin{abstract}
Traditionally studies on Happiness have been using income as a proxy for wellbeing and quality of life using GDP to measure progress of nations. We need to understand here that while income is an objective measure, Happiness is a subjective measure. One of the key criticisms leveled against GDP is that it does not take into account sustainability. Sometimes growth may be there but not achieved through sustainable means, thereby risking the future. On the flip side economic growth itself may not be sustainable in some cases. So can we depend on economic factors alone to be happy? In the past decade or so more and more countries are looking at the "Beyond GDP "agenda. In 2011 the OECD developed a framework for measuring wellbeing that can reflect and support development of measurement frameworks on a national level. There are a sizeable number of Latin American countries scoring consistently high on the Happiness index despite a number of socio economic issues. The recently published World Happiness report (2018) suggests that this is not a mere coincidence. It is based on the fact that Happiness in Latin America has social foundations. UAE lists in the top 20 countries with a happiness index of 6.774. (Source: World Happiness ranking 2015-17). This is the first ever attempt to superimpose the Latin American happiness model on the UAE local community to arrive at a sustainable happiness model for the UAE.
\end{abstract}

Keywords: Sustainable happiness; Non Economic factors; UAE Happiness Index; Latin American model of Happiness, Interpersonal relations.

\section{Introduction}

UAE lists in the top 20 countries with a happiness index of 6.774. (Source: World Happiness ranking 2015-17). For the same period Finland is ranked number 1 with a score of 7.632.Traditionally studies on Happiness have been using income as a proxy for wellbeing and quality of life using GDP to measure progress of nations. We need to understand here that while income is an objective measure, Happiness is a subjective measure. One of the key criticisms leveled against GDP is that it does not take into account sustainability. The Happiness Report -2018, talks of a 4 point happiness gap between the happiest and unhappiest countries and three points out of these four (which is 75\%) is explained by the following 6 factors: Togetherness (sense of community) ;money; health; freedom; trust and kindness. (Wiking Mike, 2017) The same https://doi.org/10.30585/icabml-cp.v2i1.278

(c) 2018 the Authors. Production and hosting by Avicenna FZ LLC. on behalf of Dubai Business School, University of Dubai - United Arab Emirates. This is an open access article under the CC BY-NC license. 
author says that when he asked people across the world to think of their good times, it was almost always about memories of being with other people, be it their family or with their friends. Whilst evidence says that the more often people meet, the happier they are, it is also about the quality of their relationships. The author says the important thing is not just about seeing and meeting people but of connecting with them. "Humans are essentially social animals. We live together in romantic relationships, family groups, neighborhoods and communities. Our relationships can be a source of support, a source of identity and a source of fun."(Source Global Happiness Policy Report-2018,released during the Global Happiness Summit at UAE; Pg. 131).The report explains this phenomenon through the Warmth of interpersonal relationships, Centrality of the family structure and relative disregard for Materialism in these countries. These countries score high on several measures like life evaluation scores and positive effect scores (Source: Gallup World Poll, 2006-16). In the past decade or so more and more countries are looking at the "Beyond GDP "agenda. in 2011 the OECD developed a framework for measuring wellbeing that can reflect and support development of measurement frameworks on a national level. The Latin American case definitely shows that there is more to life than income. Since UAE already ranks high in Happiness, it now needs to focus on the "soft factors" to be able to sustain the high levels and improve its current position to the top 10 countries in coming times. UAE is already working on multiple fronts using both people and technology power to scale new heights.

The researcher's interest in UAE stems from her long stint in the UAE combined with the fact that UAE is working earnestly to develop a more sustainable model of happiness. It is the firm conviction of the researcher that focusing on noneconomic factors can create substantial impact to the current Happiness model being pursued in UAE.

The study uses secondary data present in the World Happiness Report, 2018 along with a initial exploratory research using personal interviews with a restricted group of 30 individuals of the Emirati community. The study is intended only as an initial study that will give greater insights for further research in this area culminating in the realignment of the $U A E$ Happiness strategy based on non-economic measures.

\section{Brief Literature Review}

\begin{tabular}{|l|l|l|l|l|}
\hline $\begin{array}{l}\text { S } \\
\text { no }\end{array}$ & Year & Authors & Research & Finding \\
\hline 1 & 2002 & $\begin{array}{l}\text { Diener and } \\
\text { Seligman }\end{array}$ & $\begin{array}{l}\text { Researched the qualities that differentiated } \\
\text { happiest from less happy people }\end{array}$ & $\begin{array}{l}\text { It was not gender or socio } \\
\text { economic status but close } \\
\text { friends that distinguished } \\
\text { these 2 groups }\end{array}$ \\
\hline 2 & 2017 & $\begin{array}{l}\text { Helliwell, } \\
\text { Huang and } \\
\text { Wang }\end{array}$ & $\begin{array}{l}\text { They researched the influence of societal social } \\
\text { strengths on societal life expectancy }\end{array}$ & $\begin{array}{l}\text { Influence of societal social } \\
\text { effects exceeds the } \\
\text { influence of combined } \\
\text { effects of societal life } \\
\text { expectancy. }\end{array}$ \\
\hline 3 & 2013 & $\begin{array}{l}\text { Aknin and } \\
\text { Dunn }\end{array}$ & $\begin{array}{l}\text { Can giving support boost wellbeing to the giver } \\
\text { people from 136 countries } \\
\text { showed that giving money } \\
\text { to others pays rich } \\
\text { dividends on happiness } \\
\text { scores }\end{array}$ \\
\hline 4 & 1995 & $\begin{array}{l}\text { Baumister and } \\
\text { Leary }\end{array}$ & $\begin{array}{l}\text { They researched the innate human need to form } \\
\text { bonds }\end{array}$ & $\begin{array}{l}\text { Absence of strong social } \\
\text { bonds can have } \\
\text { deleterious consequences } \\
\text { for health and wellbeing of } \\
\text { individuals }\end{array}$ \\
\hline
\end{tabular}




\begin{tabular}{|c|c|c|c|c|}
\hline 5 & 2018 & $\begin{array}{l}\text { World } \\
\text { Happiness } \\
\text { Report }\end{array}$ & $\begin{array}{l}\text { Roughly three quarters of the difference in } \\
\text { happiness between countries is accounted for by } \\
6 \text { factors and one of them is social Support }\end{array}$ & $\begin{array}{l}\text { This is somewhat } \\
\text { measured by asking } \\
\text { people whether they have } \\
\text { somebody they can rely } \\
\text { on in times of need. }\end{array}$ \\
\hline 6 & 2017 & Wiking Meik & $\begin{array}{l}\text { When you ask people across the globe about } \\
\text { their good times it is always with other people in } \\
\text { their memories }\end{array}$ & $\begin{array}{l}\text { However it is not just } \\
\text { about quantity. It is also } \\
\text { about quality of } \\
\text { relationships. }\end{array}$ \\
\hline 7 & 2018 & Diener, Ed & $\begin{array}{l}\text { Over last few decades the research on wellbeing } \\
\text { has grown exponentially. One of the questions } \\
\text { often asked is about the factors contributing to } \\
\text { happiness. }\end{array}$ & $\begin{array}{l}\text { In all researches, one } \\
\text { factor emerges time and } \\
\text { again as a particularly } \\
\text { strong influence and it is } \\
\text { High quality social } \\
\text { relationships }\end{array}$ \\
\hline 8 & 2015 & $\begin{array}{l}\text { Ricard, } \\
\text { Matthieu }\end{array}$ & $\begin{array}{l}\text { Happiness rises with social involvement in } \\
\text { volunteer organizations, practice of sports or } \\
\text { music and membership in leisure clubs. It is } \\
\text { closely tied to the maintenance and quality of } \\
\text { private relationships }\end{array}$ & \\
\hline 9 & 2014 & Dolan, Paul & $\begin{array}{l}\text { People around you can influence you more than } \\
\text { you think. Humans have the tendency to } \\
\text { unconsciously mimic and absorb the emotions of } \\
\text { those around us. There is believed to be a close } \\
\text { connection between our moods and that of } \\
\text { those around us. }\end{array}$ & $\begin{array}{l}\text { We are very much } \\
\text { affected by the people } \\
\text { that we move with both at } \\
\text { work and in your personal } \\
\text { life. The role of people } \\
\text { cannot be therefore } \\
\text { overlooked }\end{array}$ \\
\hline 10 & 2015 & $\begin{array}{l}\text { Diener, Biswas; } \\
\text { Ricard } \\
\text { Matthieu }\end{array}$ & $\begin{array}{l}\text { Psychologists are trying to analyze about the so } \\
\text { called "Happy poor" who are more cheerful than } \\
\text { many rich but stressed people. }\end{array}$ & $\begin{array}{l}\text { We are getting more and } \\
\text { more evidence based on } \\
\text { research that wealth and } \\
\text { happiness are probably } \\
\text { not positively co related }\end{array}$ \\
\hline 11 & 2015 & $\begin{array}{l}\text { Ricard, } \\
\text { Matthieu }\end{array}$ & $\begin{array}{l}\text { The rise in depression and suicide rate among } \\
\text { teenagers in US and Sweden according to a } \\
\text { recent study is due to a decreased sense of trust } \\
\text { among people, the breaking up of families and } \\
\text { portrayal of violence through TV and the fact that } \\
\text { people increasingly live alone. And fewer persons } \\
\text { are involved in sports or culture or in serving } \\
\text { their elders unlike the past }\end{array}$ & $\begin{array}{l}\text { Loneliness and it's } \\
\text { attendant issues are being } \\
\text { cited as one of the many } \\
\text { reasons for increase in } \\
\text { depression among } \\
\text { teenagers and rise in } \\
\text { suicidal tendencies }\end{array}$ \\
\hline
\end{tabular}

To summarize the findings from literature review:

- Social bonding seemed to have visible positive effects on the overall health of individuals and society

- Absence of close relationships seemed to have deleterious effect on the health of certain individuals in western world.

- Most of the research studies emphasized the positive effect of high quality social relationships. 
These findings led the researcher to do more study of the world happiness report findings especially w.r.t Latin America and thus led to the idea for this study.

\section{Research Design}

Latin America is beset with a number of problems both social, economic and some political. The economic indicators for Latin American countries does not sufficiently explain the consistently high happiness levels in Latin American countries on multiple areas as seen from the research presented in the above ( Source: Chapter 6 of the "World Happiness Report-2018"; edited by John. F. Helliwell, Richard Layard and Jeffrey Sachs.) As a result the researchers in the above report concluded that there must be some other factors contributing to happiness in those countries and they came upon the concept of Interpersonal relationships in the context of Latin America.

Specific research findings that are of interest are as below:

- Evaluation of life in Latin American countries is high w.r.t what social and income indicators would predict

- The affective state shows very high figures for almost all Latin American even though some of them have low income, corruption and serious social issues.

As a result the researchers concluded that there must be some other factors contributing to the happiness in those countries and they came upon the concept of interpersonal relationships in the context of Latin America.

(Source: pg 120, Chapter 6 of the "World Happiness Report-2018"; edited by John.F. Helliwell, Richard Layard and Jeffrey Sachs.)

\section{Research instrument}

The researchers in the above report believe that Latin Americans give more importance to the relational realm as compared to materialistic pursuits. Many Latin Americans have "Making my parents proud" as one of the main goals of their life. A large proportion of them also believe that elderly people should be supported by their family members and not by external institutions as is common in the western world. In a world where success and happiness are viewed solely on materialistic terms, Latin America stands out as a rare and strange example. The below diagram best represents the Latin American Social model. A questionnaire that was intended to serve as an interview guide was developed consisting of a total of 21 statements which were tested for both Quantitative as well as Qualitative responses. The quantitative responses used a 5 point Likert scale while the qualitative responses were intended to test the depth / intensity of the feelings portrayed in the selected viewpoints. Questions were designed to cover all elements of the below depicted model covering nuclear, extended family, friends and intensity of the relationships.

The study used random sampling method to locate Emirati candidates based on their willingness to participate in the survey. Considering that they are a closed community the kind of positive response received by the survey was a very positive aspect of this study. Many of the respondents not only proactively participated in the interview and gave suggestions to enhance the study in future as well were willing to contributing to the survey by referring their friends as well as showed enthusiasm to participate in future studies of this research. The in depth interview lasted for $30-40$ minutes in each case. During the interview they shared many intricate facets and brought valuable insights in enhancing the quality of the study. As a researcher there are several hurdles in getting responses which was contrary in this case despite the busy schedules of some of the respondents. 


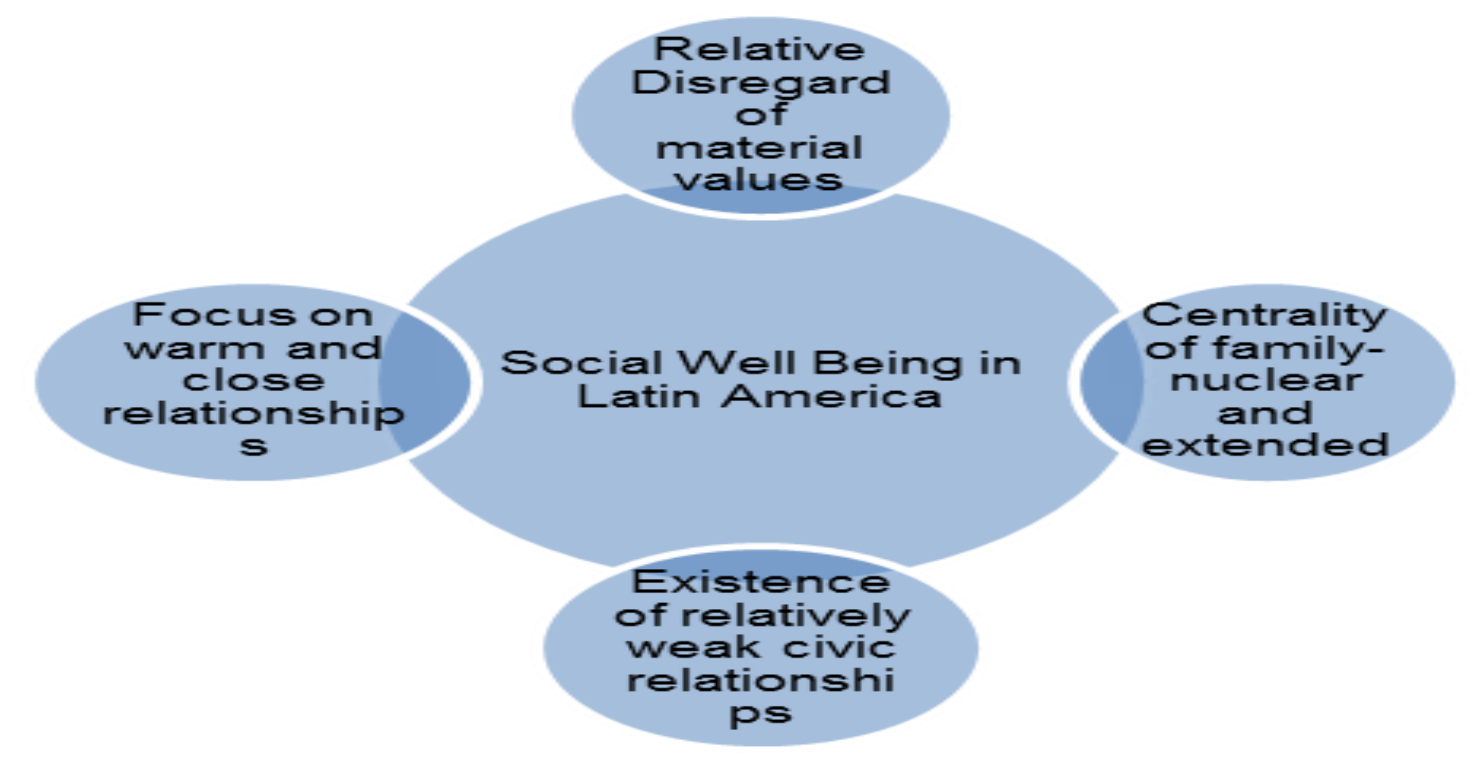

Latin America is much more than a mere collection of countries that are in the same geographical area or those that share a similar language. It is quite possible to think of Latin American culture as one that is based on close and warm interpersonal relationships and where enjoyment of positive affective state predominates. Latin American culture seems to have emerged from certain historical processes that were common to all countries in this category. Coexistence with rather than dominance of nature was the central value of many groups that came to reside in Latin America through various conquests. These people mixed sometimes with the original inhabitants to produce a mixed breed with common values. The values that they imbibed helped create a society that was not as much interested in changing the social and natural context as it was in living within it.The extended family values of the conquerors blended well with the communitarian values of the indigenous groups, thus generating societies where interpersonal relations centered in the family and relatives were dominant with a corresponding disinterest or lack of involvement in society or civic life.

There are many things common between the Latin American and Emirati culture w.r.t relationships and family ties. Emiratis trace their origins to Bedouins or tribes who believe in community living and close family ties. Extended family networks exist even today among Emiratis. The study has used in depth interviews with a focused group of Emiratis of both gender of mixed age group to explore how much of the above mentioned values still have meaning in the current day context.

This study was conducted in the form of in depth interviews of 30 Emiratis covering both genders and mixed age groups ranging from 25 to 60 yrs. The interview had 2 sections with 21 statements drawn right out of the Latin American Social model. These were tested using a 5 point Likert scale as well as probed further for more detailed responses. There seemed to be a high willingness among participants to take part in the survey coupled with curiosity about the reasons for the study. Many enjoyed the experience thus giving the researcher the feeling that the topic was something they cared about. Many of the surveyed respondents agreed to be available for further research if and when needed. The survey mainly focused on superimposing the Latin American social model on the Emirati culture and check for 
similarities and dissimilarities between the 2 cultures. This was intended to serve as a guide for the direction of future research in this area for developing a sustainable Happiness model for UAE based on non-economic criteria.

\section{Findings}

Table 1: Comparison of Latin American Social model with Emirati responses.

\begin{tabular}{|c|c|c|c|}
\hline $\begin{array}{l}\text { Features of Latin American } \\
\text { Countries social model }\end{array}$ & $\begin{array}{l}\text { Questions in the survey that } \\
\text { relay the same sentiment }\end{array}$ & $\begin{array}{l}\text { Emirati scores to } \\
\text { the statement }\end{array}$ & $\begin{array}{l}\text { Justifying remarks from } \\
\text { the survey }\end{array}$ \\
\hline $\begin{array}{l}\text { Latin Americans spend much } \\
\text { time and resources in } \\
\text { nurturing personal relations }\end{array}$ & $\begin{array}{l}\text { We need to invest time and } \\
\text { resources in building long } \\
\text { term relationships }\end{array}$ & $85 \%$ & $\begin{array}{l}\text { 1) This is what life is } \\
\text { about. One day when you } \\
\text { are gone you need people } \\
\text { who can help the future } \\
\text { generations } \\
\text { 2) We already have it in } \\
\text { our culture, but it is not } \\
\text { as strong as before. We } \\
\text { need to regain lost } \\
\text { ground. }\end{array}$ \\
\hline $\begin{array}{l}\text { Close and warm relations in } \\
\text { Latin America also extends to } \\
\text { friends, neighbors and } \\
\text { colleagues }\end{array}$ & $\begin{array}{l}\text { 1) Close Friends are } \\
\text { like family. They are } \\
\text { present in our good } \\
\text { and bad times } \\
\text { 2) We need to help } \\
\text { and support our less } \\
\text { able friends }\end{array}$ & $\begin{array}{l}69 \% \\
79 \%\end{array}$ & $\begin{array}{l}\text { 1) Sometimes they are } \\
\text { more important than } \\
\text { family as they can } \\
\text { influence me more than } \\
\text { my family. } \\
\text { 2) Of course. It is karmic. } \\
\text { 3) Once I was very sick and } \\
\text { my friend was there for } \\
\text { me. }\end{array}$ \\
\hline $\begin{array}{l}\text { The family both nuclear and } \\
\text { extended is a central } \\
\text { institution in Latin America } \\
\text { and an important source of } \\
\text { positive affect and purpose in } \\
\text { life }\end{array}$ & $\begin{array}{l}\text { 1) Staying with parents } \\
\text { provides guidance } \\
\text { and support to the } \\
\text { individual } \\
\text { 2) }\end{array}$ & $80 \%$ & $\begin{array}{l}\text { 1)Because you will get } \\
\text { support and your spouse } \\
\text { will blend well with your } \\
\text { family values } \\
\text { 2)If you are starting your } \\
\text { career or married life they } \\
\text { are a huge support }\end{array}$ \\
\hline $\begin{array}{l}\text { Latin American people tend } \\
\text { to live longer with their } \\
\text { families and do not } \\
\text { necessarily leave them when } \\
\text { they become adults }\end{array}$ & $\begin{array}{l}\text { It is all right to live with your } \\
\text { parents even as an adult }\end{array}$ & $82 \%$ & $\begin{array}{l}\text { 1) In Emirati houses we } \\
\text { live with our parents and } \\
\text { grandparents. This is } \\
\text { normal. } \\
\text { 2) It gives you a pure } \\
\text { family feeling. } 4 \\
\text { generations together in a } \\
\text { house- a great feeling }\end{array}$ \\
\hline $\begin{array}{l}\text { It is common in Latin America } \\
\text { for elder parents to live with } \\
\text { their adult children and their } \\
\text { grandchildren }\end{array}$ & $\begin{array}{l}\text { 1)family members need to } \\
\text { take care of their elderly } \\
\text { family persons }\end{array}$ & $92 \%$ & $\begin{array}{l}\text { 1)They are a blessing to us } \\
\text { and the nation.. We need } \\
\text { to return their services to } \\
\text { the family and society. }\end{array}$ \\
\hline
\end{tabular}




\begin{tabular}{|c|c|c|c|}
\hline & & & $\begin{array}{l}\text { 2)The way you take care } \\
\text { of your elders sets an } \\
\text { example for your children }\end{array}$ \\
\hline $\begin{array}{l}\text { Family members play an } \\
\text { important role in child } \\
\text { rearing }\end{array}$ & $\begin{array}{l}\text { Grandparents have a right to } \\
\text { spend time with their } \\
\text { grandchildren }\end{array}$ & $85 \%$ & $\begin{array}{l}\text { It is highly recommended } \\
\text { as children will learn the } \\
\text { right values and preserve } \\
\text { the culture as well }\end{array}$ \\
\hline $\begin{array}{l}\text { Both Brazil and Chile ( both } \\
\text { latin American nations) } \\
\text { believe that we must take } \\
\text { care of ourselves and our } \\
\text { family before taking care of } \\
\text { others }\end{array}$ & $\begin{array}{l}\text { You should take care of } \\
\text { yourself and your family } \\
\text { before taking care of other } \\
\text { people }\end{array}$ & $60 \%$ & $\begin{array}{l}\text { 1) Family is first always. } \\
\text { 2) This is in our religion } \\
\text { too. We need to take care } \\
\text { of our family, extended } \\
\text { family, then neighbors } \\
\text { and friends }\end{array}$ \\
\hline $\begin{array}{l}\text { Latin Americans strongly } \\
\text { believe that family must play } \\
\text { a central role in raising kids } \\
\text { as well as taking care of } \\
\text { elders }\end{array}$ & $\begin{array}{l}\text { 1) Underage kids } \\
\text { need the care of } \\
\text { their family } \\
\text { members }\end{array}$ & $90 \%$ & $\begin{array}{l}\text { 1) To raise a generation } \\
\text { with values, compassion } \\
\text { and faith, family members } \\
\text { must play a huge role. } \\
\text { 2) We were raised that } \\
\text { once a family, is always a } \\
\text { family and we have a } \\
\text { great responsibility to take } \\
\text { care of our parents in that } \\
\text { sense. }\end{array}$ \\
\hline $\begin{array}{l}\text { Latin Americans believe that } \\
\text { making parents proud and } \\
\text { watching children grow gives } \\
\text { them great joy. }\end{array}$ & $\begin{array}{l}\text { 1) One of my goals is } \\
\text { to make my parents } \\
\text { proud } \\
\text { 2) Watching children } \\
\text { grow is the greatest } \\
\text { joy }\end{array}$ & $\begin{array}{l}91 \% \\
91 \%\end{array}$ & $\begin{array}{l}\text { 1) Whatever I do should } \\
\text { be in proportion to their } \\
\text { vision. what I do should in } \\
\text { pride and happiness for } \\
\text { them } \\
\text { 2) Children are our true } \\
\text { assets and capital. We } \\
\text { should help them to find } \\
\text { their future. }\end{array}$ \\
\hline $\begin{array}{l}\text { Involvement and interaction } \\
\text { with extended family is quite } \\
\text { high in both Brazil and Chile }\end{array}$ & $\begin{array}{l}\text { When there is a } \\
\text { celebration it is } \\
\text { normal to include } \\
\text { extended family } \\
\text { 2) If the family is } \\
\text { passing through } \\
\text { troubles, the } \\
\text { extended family is } \\
\text { there to help }\end{array}$ & $\begin{array}{r}88 \% \\
77 \%\end{array}$ & $\begin{array}{l}\text { 1) We are a large family } \\
\text { almost } 400 \text {. When thee is } \\
\text { marriage or graduation or } \\
\text { Eid we all meet } \\
\text { 2) it is common for us to } \\
\text { meet every Friday at our } \\
\text { grandparents home. }\end{array}$ \\
\hline $\begin{array}{l}\text { In Brazil and Chile they visit } \\
\text { their friends as often as } \\
\text { every day. }\end{array}$ & $\begin{array}{l}\text { I visit my closest friend } \\
\text { several times a month }\end{array}$ & $72 \%$ & $\begin{array}{l}\text { 1) We meet every Friday } \\
\text { in cafes. We support each } \\
\text { other with ideas and } \\
\text { network } \\
\text { 2) We try to meet on } \\
\text { weekends and other } \\
\text { special holidays. }\end{array}$ \\
\hline
\end{tabular}




\begin{tabular}{|c|c|c|c|c|}
\hline $\begin{array}{l}\text { Gathering with relatives in } \\
\text { Mexico is as much as } 77 \% \text { as } \\
\text { against } 54 \% \text { in America }\end{array}$ & & $\begin{array}{l}\text { I visited my } \\
\text { uncle/aunt more } \\
\text { than twice in last } 4 \\
\text { weeks } \\
\text { I visited my cousins } \\
\text { more than twice in } \\
\text { last } 4 \text { weeks }\end{array}$ & $\begin{array}{l}63 \% \\
51 \%\end{array}$ & $\begin{array}{l}\text { 1) During Eid and } \\
\text { Ramadhan as well as } \\
\text { during celebrations or sad } \\
\text { times. } \\
\text { 2) Some close relatives we } \\
\text { meet often and others } \\
\text { only during occasions due } \\
\text { to paucity of time. }\end{array}$ \\
\hline
\end{tabular}

1) The very high scores by Emiratis for majority of the statements clearly show that the Latin American model can be superimposed on the Emirati social fabric,and this will form the basis for further research.

2) The results clearly show that very similar strong family ties as in Latin America exist in UAE too. However they seem to be under threat from current challenges owing to the superfast and accelerated growth and future ambitions of this nation. There is a predominant group among the surveyed ones that are still sticking to their old beliefs and culture of staying together and bonding. There is a small percentage of these who are a little more ambitious and want to move ahead and need the space to be individual while enjoying the benefits of living together. They want a healthy mix of the traditional beliefs and modernity.

3) Whilst close bonding between family members, including extended family do exist, individuals are being increasingly pressured by too many things to juggle at work and home. The invasion of social media into personal space is posing a serious threat to the quality of relationships. Emiratis do try to make time for their immediate and extended family members and they feel that this is a strong support system for them which the expats do not have. Intergenerational dependence is quite common. However Emiratis also have the affordability to have maids and domestic help to take care of their kids and/ parents and they feel that this is making them lose out on the bonding.

4) The social framework for the Emirati society based on the researcher's survey is comprised of three distinct circles:

The core inner circle consists of the immediate family which includes self, my children and my parents. The second slightly wider circle comprises of close cousins and aunts and uncles and friends. The third and last outer circle consists of Extended family essentially made up of distant cousins, aunts and uncles. Time and energy invested in relationships strictly follows this pattern with utmost concern for own parents, children and grandparents, followed by close friends and lastly extended family.

So we can represent the Social model as three concentric circles if we were to put it in a very simplistic. However for purposes of like to like comparison, the researcher has developed a model for Emiratis on similar lines of the Latin American model as depicted below. 


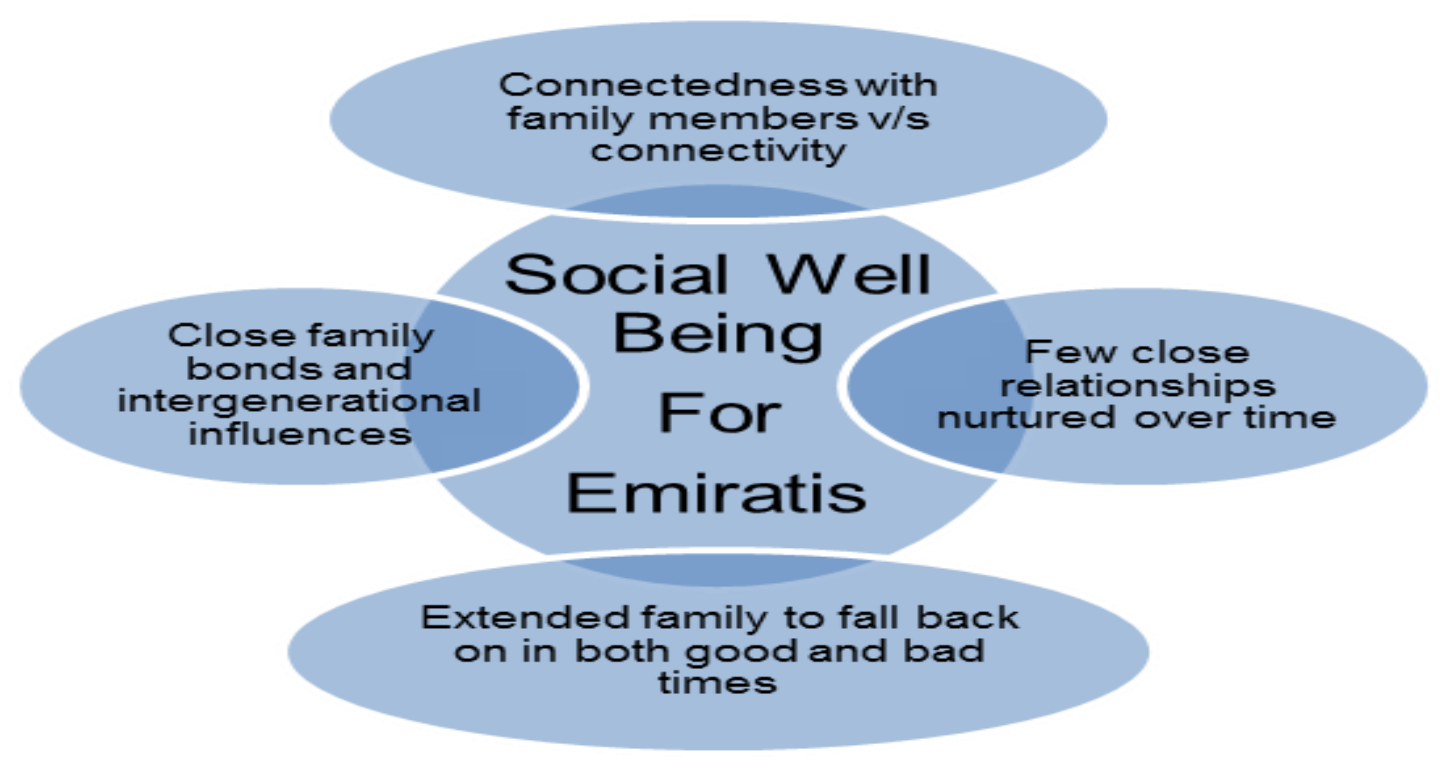

\section{CONCLUSIONS}

There are many lessons to learn from the Latin American Example:

1) There is a strong need to go beyond objective measures when you are trying to assess people's situation. In this sense the WHR -2018 believes that subjective wellbeing indices help us in understanding the values that people hold dear in a certain group or nation. Since values vary from one group to another, it helps to have subjective measures to take care of variances when making cross cultural assessments

2) Latin American example clearly shows that there is more to life than income. It also tells us that genuine, warm and person based relations substantially contribute to happiness.

3) In the study the respondents who were Emiratis (local citizens of UAE) gave valuable suggestions on how they can increase their interpersonal bonding with close family, extended family and friends. This will form the subject matter for yet another study in future.

4) Both Latin America nd UAE should focus on strengthening the rich culture of the past that they have and use that to get sustainable happiness.

Implications for Future Research

If explored in depth, such research studies can help the top leadership of Dubai and UAE to review and reorient their Happiness model and policies based on these findings. This would then lead us to a more sustainable model of happiness that is here to stay and not depending on economic factors. It will also help create a more tolerant society built on trust, respect and family values. In view of the low population level of the Emiratis such a model will also help in preserving and protecting their community from external influences in light of High tech initiatives happening in UAE. There is definitely a lot of synergy in values between Emirati thinking and the Latin American example. The researcher is of the opinion that further research could be carried out in future as below:

- Intergenerational views on economic $\mathrm{v} / \mathrm{s}$ non-economic factors .r.t happiness in any one group or both groups

- A comparative study of the values of Expats v/s Emiratis w.r.t the Latin American example.

- A more focused research on any one community (Either Emiratis or Expats) The possibilities are numerous and exciting. 
Limitations

The current study clearly omitted expats as the researcher would like to isolate the responses of Emiratis first and deal with the expat population separately on the same issue if the need arises. UAE has the most diverse expat community in terms of nationalities, age group and income group and the sampling plan needs to be done meticulously in this case. Also there is more likelihood that the Family model applies more to locals as they have extended families present while most expats live in nuclear families or even as bachelors with their families continuing to live in their home countries and hence the above study may not be relevant to such groups.

\section{Beyond GDP}

\section{"The GNP measures everything in short, except that which makes life worthwhile"- Robert F Kennedy.}

The beyond GDP agenda has progressed significantly in the past decade or so with a certain amount of push by the OECD.In 2011, it pursued the development of a framework that measured wellbeing that both reflected and supported the development of frameworks at a national level by interested countries.

The Global Happiness Policy Report, 2018 has an entire chapter (Chapter: 8) devoted to measurement of well-being and case studies depicting measurement of social well-being being done currently in several countries. Some of them are Equador, Germany, Australia, Austria, Finland etc. A small sample of the major initiatives is presented here.

Table 2: Wellbeing Measurement Initiatives around the world that can be emulated:

\begin{tabular}{|c|c|c|c|}
\hline Country & Agency & Description of study & $\begin{array}{l}\text { Wellbeing } \\
\text { measures }\end{array}$ \\
\hline Austria & Statistics Austria & $\begin{array}{l}\text { The agency publishes an } \\
\text { annual report since } 2012 \text { on } \\
30 \text { key indicators categorized } \\
\text { into } 3 \text { dimensions, material } \\
\text { wealth, quality of life and } \\
\text { environmental sustainability }\end{array}$ & $\begin{array}{l}\text { Subjective } \\
\text { wellbeing measure } \\
\text { included in this } \\
\text { study was life } \\
\text { satisfaction on a } \\
\text { scale of } 1 \text { to } 10 .\end{array}$ \\
\hline Slovenia & $\begin{array}{l}\text { IMAD, SURS, } \\
\text { ARSO, and NIJZ }\end{array}$ & $\begin{array}{l}\text { Indicators of wellbeing have } \\
\text { been developed as part of } \\
\text { National Development Strategy } \\
\text { of Slovenian government. The } \\
\text { indicators are in } 3 \text { categories: } \\
\text { material, social and } \\
\text { environmental wellbeing. }\end{array}$ & $\begin{array}{l}\text { The framework } \\
\text { includes both life } \\
\text { satisfaction and } \\
\text { happiness }\end{array}$ \\
\hline Italy & $\begin{array}{l}\text { National Council } \\
\text { for Economy and } \\
\text { Lab our }\end{array}$ & $\begin{array}{l}\text { The Equitable and sustainable } \\
\text { wellbeing project led to the } \\
\text { development of a wellbeing } \\
\text { framework }\end{array}$ & $\begin{array}{l}\text { This includes life } \\
\text { satisfaction, Leisure } \\
\text { time satisfaction, } \\
\mathrm{p} \text { [positive and } \\
\text { negative } \\
\text { judgements of } \\
\text { future perspective } \\
\text { as some of the } \\
\text { indicators of } \\
\text { subjective well } \\
\text { being }\end{array}$ \\
\hline
\end{tabular}




\section{Source: Global Happiness Policy Report 2018; table 2.1: Selected National Wellbeing Measurement initiatives and Indicator sets; pg :205-206.}

A common feature of these national initiatives is that while they all recognize people wellbeing as being a multidimensional construct, they often include measures of people's subjective wellbeing ( or happiness) as one of the key components. One more point to be noted is that many of these frameworks were developed by a government agency or by a combination of policy making bodies in yet other countries, thereby suggesting that the underlying motive is to provide additional information beyond GDP, without necessarily wanting to embed this into an explicit policy framework. However we need to understand that measuring wellbeing is not an end in itself. It should be used in conjunction with other data for more meaningful policy making as well as by the general public.

The researcher would like to emphasize that this initial study can pave the way for more research on how Emiratis can capitalize and strengthen their relational sphere to develop sustainable happiness as individuals and on the other hand how can policy makers of the UAE happiness model incorporate sufficient and necessary wellbeing measures in the model to create sustainable happiness for UAE.

\section{REFERENCES}

Books

Dolan, Paul, Happiness by Design, Penguin books, UK, 2014

Ricard Matthieu, "Happiness-A guide to developing life's most Important skill", Atlantic books, UK, 2017.

Seligman Martin E.P, 2013,"Authentic Happiness: Using the New Positive Psychology to Realize Your Potential for Lasting Fulfillment", Atria Paperback edition.

Wiling Meik, 2017, "The little Book of Lykke: The Danish Search for the World's Happiest People”, Penguin House, UK, 2017.

Reports

Global Happiness Policy Report, World Government Summit, 2018

Helliwell John .F, Layard Richard, Sachs Jeffrey.D, World Happiness Report, 2018.

World Happiness Report, Chapter 5: Happiness in Latin America has social Foundations 